Diabetologia (1994) 37: 300-307

\title{
Effect on insulin sensitivity of angiotensin converting enzyme inhibitors with or without a sulphydryl group: bradykinin may improve insulin resistance in dogs and humans
}

\author{
M. Uehara, H. Kishikawa, S. Isami, K. Kisanuki, Y. Ohkubo, N. Miyamura, T. Miyata, T. Yano, M. Shichiri \\ Department of Metabolic Medicine, Kumamoto University School of Medicine, Kumamoto, Japan
}

Summary The present study compared the effect on insulin sensitivity of ACE inhibitors with a sulphydryl group (captopril) or those without a sulphydryl group (delapril and enalapril) during the hyperinsulinaemic euglycaemic clamp test in both animal and clinical experiments. A possible contribution of bradykinin to the improvement of insulin sensitivity by ACE-inhibition was also studied. In healthy control and depancreatized dog experiments, administration of captopril either intravenously $\left(3.0 \mathrm{mmol} \cdot \mathrm{kg}^{-1}\right)$ or orally $(5.0 \mathrm{mmol}$. $\mathrm{kg}^{-1}$ ) increased insulin sensitivity indices and plasma bradykinin concentrations. In comparison, intravenous administration of an active metabolite of delapril $\left(3.0 \mathrm{mmol} \cdot \mathrm{kg}^{-1}\right)$ and oral administration of either delapril or enalapril $\left(5.0 \mathrm{mmol} \cdot \mathrm{kg}^{-1}\right)$ showed slight, but not significant increases in insulin sensitivity indices and plasma bradykinin concentrations. Infusion of a bradykinin antagonist (N- $\alpha$-adamantaneacetyl-DArg-[Hyp $\left.{ }^{3}, \mathrm{Thi}^{5,8}, \mathrm{D}-\mathrm{Phe}^{7}\right]$-bradykinin $)\left(0.5 \mathrm{nmol} \cdot \mathrm{kg}^{-1}\right.$. $\mathrm{min}^{-1}$ ) abolished the effect of captopril on insulin sensitivity. Furthermore, intravenous administration of bradykinin $\left(0.1 \mathrm{nmol} \cdot \mathrm{kg}^{-1} \cdot \mathrm{min}^{-1}\right)$ increased insulin sensitivity indices. In clinical experiments, insulin sensitivity indices decreased in the following order: normotensive healthy subjects, hypertensive non-diabetic patients, normotensive NIDDM patients and hypertensive NIDDM patients. In these four groups, oral administration of captopril $\left(2.0 \mathrm{mmol} \cdot \mathrm{kg}^{-1}\right)$ significantly increased insulin sensitivity indices, and a concomitant increase in plasma bradykinin concentrations was observed. By contrast, oral administration of enalapril or delapril showed slight, but not significant effects on insulin sensitivity indices and plasma bradykinin concentrations. From these studies, it is concluded that ACE inhibitors with a sulphydryl group have more potent action on the improvement in insulin sensitivity than those without a sulphydryl group. Bradykinin may also possibly be involved in the mechanism underlying the improvement in insulin sensitivity associated with ACE-inhibition. [Diabetologia (1994) 37:300-307]

Key words Diabetes mellitus, hypertension, angiotensin converting enzyme inhibitor, sulphydryl group, insulin sensitivity, bradykinin.
Hypertension commonly occurs in patients with diabetes mellitus [1]. Although a number of antihypertensive drugs are currently available for the treatment of hy-

Received: 27 April 1993

and in final revised form: 12 October 1993

Corresponding author: Dr. M. Uehara, Department of Metabolic Medicine, Kumamoto University School of Medicine, 1-1-1, Honjo, Kumamoto, 860, Japan

Abbreviations: ACE, Angiotensin converting enzyme; NIDDM, non-insulin-dependent diabetes mellitus; IDDM, insulin-dependent diabetes mellitus; AEP, artificial endocrine pancreas. pertension, most of these drugs, except for ACE inhibitors, $\alpha$-adrenergic blockers and $\mathrm{Ca}^{2+}$-channel blockers, are known to impair glucose metabolism [2]. Therefore, ACE inhibitors are often used to treat hypertension associated with diabetes because of their manageability, efficacy and low frequency of side effects.

Currently available ACE inhibitors can be divided into two categories: those with a sulphydryl group (captopril) or those without a sulphydryl group (enalapril and delapril) [3]. The sulphydryl group of ACE inhibitors is associated with a number of characteristics including an anti-atherogenic effect, suppression of free radical production and adverse skin reactions [4-6]. 
Table 1. Clinical characteristics of patients enrolled in the study

\begin{tabular}{|c|c|c|c|c|c|c|c|c|}
\hline & Age (years) & $\begin{array}{l}\text { Sex (male/ } \\
\text { female) }\end{array}$ & $\begin{array}{l}\mathrm{BMI} \\
\left(\mathrm{kg} / \mathrm{m}^{2}\right)\end{array}$ & $\begin{array}{l}\text { Duration of } \\
\text { diabetes } \\
\text { (years) }\end{array}$ & $\begin{array}{l}\sum \text { IRI } \\
(\mathrm{nmol} / \mathrm{l})\end{array}$ & $\begin{array}{l}\mathrm{HbA}_{1 \mathrm{C}} \\
(\%)\end{array}$ & $\begin{array}{l}\text { Systolic/diastolic } \\
\text { blood pressure } \\
(\mathrm{mmHg})\end{array}$ & Treatment \\
\hline $\begin{array}{l}\text { Normotensive healthy } \\
\text { subjects }(n=8)\end{array}$ & $53.2 \pm 2.6$ & $6 / 2$ & $23.0 \pm 1.1$ & - & $1.2 \pm 0.1$ & $5.4 \pm 0.2$ & $130 \pm 5.0 / 80 \pm 3.2$ & - \\
\hline $\begin{array}{l}\text { Hypertensive non- } \\
\text { diabetic patients } \\
(n=8)\end{array}$ & $56.3 \pm 4.0$ & $5 / 3$ & $22.8 \pm 1.0$ & - & $1.2 \pm 0.1$ & $5.6 \pm 0.2$ & $150 \pm 4.8^{\mathrm{a} / 92} \pm 3.4$ & No drug \\
\hline $\begin{array}{l}\text { Hypertensive NIDDM } \\
\text { patients }(n=8)\end{array}$ & $57.2 \pm 7.3$ & $5 / 3$ & $22.5 \pm 2.4$ & $11.2 \pm 0.6$ & $0.7 \pm 0.1^{\mathrm{a}}$ & $8.0 \pm 0.8^{\mathrm{a}}$ & $156 \pm 6.2^{\mathrm{a} / 94} \pm 3.6$ & Sulphonylurea \\
\hline
\end{tabular}

$\Sigma$ IRI, integrated immunoreactive insulin (IRI) values of five sampling points from 0 to 120 min during 75 -g oral glucose tolerance test. ${ }^{a} p<0.05$ vs normotensive healthy subjects

Recent studies indicate that ACE inhibitors can improve insulin sensitivity during either short-term or long-term administration. Rett et al. [7] reported that insulin sensitivity increased in normotensive patients with NIDDM about $20 \mathrm{~min}$ after oral administration of captopril. Torlone et al. [8] reported that a 2-day treatment with captopril improved insulin sensitivity in hypertensive NIDDM patients. On the other hand, there are confusing results regarding long-term administration of ACE inhibitors. Paolisso et al. [9] demonstrated that a 2-week treatment using either ACE inhibitors with or without a sulphydryl group increased insulin sensitivities in elderly hypertensive non-diabetic patients. However, other studies have shown that treatments of 3 to 9 weeks using ACE inhibitors without a sulphydryl group did not increase insulin sensitivity in patients with hypertensive NIDDM or IDDM [10-12]. It is possible, therefore, that the presence of the sulphydryl group in ACE inhibitors affects insulin sensitivity. However, the mechanism for this improvement of insulin sensitivity during ACE-inhibition remains to be elucidated. Rett et al. [7] have suggested the contribution of bradykinin, although this is still not widely accepted.

The present study was designed to compare the acute, short-term effects on insulin sensitivity of ACE inhibitors with or without a sulphydryl group using the euglycaemic clamp test in both animal and clinical experiments. In addition, the possible effect of bradykinin on insulin sensitivity was also evaluated.

\section{Materials and methods}

\section{Animal experiments}

Twenty-four male dogs weighing between 10 and $15 \mathrm{~kg}$ were used before and after total pancreatectomy. After the completion of control experiments, they were totally pancreatectomized and then maintained in a moderately hyperglycaemic state for at least 2 weeks using daily subcutaneous long-acting insulin injections (Monotard MC; Novo Nordisk Pharma. Inc., Copenhagen, Denmark). Their body weights did not change significantly during the experimental periods. Each healthy control or diabetic dog was anaesthetized after an overnight fast with an i.v. bolus infusion of $20 \mathrm{mmol} \cdot \mathrm{kg}^{-1}$ pentobarbital sodium and connected to the AEP (Model STG-22; Nikkiso Co., Ltd., Tokyo, Japan) which we originally developed [13]. A jugular vein catheter was used for insulin and glucose infusions. A femoral vein catheter was used for continuous monitoring of blood glucose by the AEP. A heparinized sterile cannula was also inserted in the opposite femoral vein for sampling venous blood. A hyperinsulinaemic euglycaemic clamp was performed and the glucose infusion rate was continuously monitored for more than $2 \mathrm{~h}$ after treatment with an ACE inhibitor.

To evaluate the effectiveness on insulin sensitivity of ACE inhibitors with or without a sulphydryl group, either captopril (ACE inhibitor with a sulphydryl group) or an active metabolite of delapril (ACE inhibitor without a sulphydryl group) dissolved in $0.15 \mathrm{~mol} / 1 \mathrm{NaCl}$ at a dose of $3.0 \mathrm{mmol} \cdot \mathrm{kg}^{-1}\left(0.6 \mathrm{mg} \cdot \mathrm{kg}^{-1}\right.$ or $1.5 \mathrm{mg} \cdot \mathrm{kg}^{-1}$, respectively) was injected as a bolus $90 \mathrm{~min}$ after the equilibration of glucose infusion rate during the hyperinsulinaemic euglycaemic clamp (experiment 1). Captopril, delapril and enalapril (ACE inhibitor without a sulphydryl group) were also administered orally at a dose of $5.0 \mathrm{mmol} \cdot \mathrm{kg}^{-1}(1.0,2.5$ and $2.5 \mathrm{mg} \cdot \mathrm{kg}^{-1}$, respectively), (experiment 2 ). Compared to captopril, the antihypertensive potencies of delapril and enalapril used in the dog experiments were estimated to be 4 and 12 times more potent, respectively; the study of the pharmacological effects on antihypertensive potencies among these ACE inhibitors has demonstrated that $25 \mathrm{mg}$ of captopril is equivalent to $15 \mathrm{mg}$ of delapril or $5 \mathrm{mg}$ of enalapril [14].

To evaluate the possible effect of bradykinin on insulin sensitivity, a bradykinin antagonist ( $\mathrm{N}-\alpha$-adamantaneacetyl-D-Arg$\left[\mathrm{Hyp}^{3}, \mathrm{Thi}^{5,8}, \mathrm{D}-\mathrm{Phe}^{7}\right]$-bradykinin, $\left.0.5 \mathrm{nmol} \cdot \mathrm{kg}^{-1} \cdot \mathrm{min}^{-1}\right)$ was infused $30 \mathrm{~min}$ before captopril injection (experiment 3 ). To confirm the effect of bradykinin on insulin sensitivity, bradykinin was infused i.v. at a low or high dose rate of 0.03 or $0.1 \mathrm{nmol}$. $\mathrm{kg}^{-1} \cdot \mathrm{min}^{-1}$, respectively, $90 \mathrm{~min}$ after equilibration of the glucose infusion rate during the hyperinsulinaemic euglycaemic clamp (experiment 4).

Twenty-four dogs were divided into four groups. Each group $(n=6)$ was assigned in either a healthy or diabetic state to one of the four experiments described. For control animals, $0.15 \mathrm{~mol} \cdot 1^{-1} \mathrm{NaCl}$ in water was infused i.v. Dogs were studied on two or three separate days within a 2 -week period before and after pancreatectomy. 


\section{Clinical experiments}

Eight normotensive healthy subjects and 24 patients were studied to compare the effects on insulin sensitivity of ACE inhibitors with or without a sulphydryl group. The group of 24 patients consisted of hypertensive non-diabetic patients $(n=8)$, normotensive NIDDM patients $(n=8)$ and hypertensive NIDDM patients $(n=8)$. Their clinical characteristics are shown in Table 1 . Hypertension in both the non-diabetic and NIDDM patients was diagnosed using the definition of the United States Joint National Committee which includes patients with more than $140 \mathrm{~mm} \mathrm{Hg}$ systolic or more than $90 \mathrm{~mm} \mathrm{Hg}$ diastolic pressure [15]. Patients were on a salt restrictive diet and showed mildly elevated blood pressures. Diabetic patients had been treated with diet therapy or sulphonylurea. The study was approved by the ethical committee at the Kumamoto University School of Medicine. Informed consent was obtained from each subject.

Hyperinsulinaemic euglycaemic clamp tests were conducted, and insulin and glucose were infused through the antecubital vein using the AEP. The ACE inhibitor $\left[2.0 \mathrm{mmol} \cdot \mathrm{kg}^{-1}\right.$ of captopril $\left(0.4 \mathrm{mg} \cdot \mathrm{kg}^{-1}\right), 2.0 \mathrm{mmol} \cdot \mathrm{kg}^{-1}$ of delapril $\left(1.0 \mathrm{mg} \cdot \mathrm{kg}^{-1}\right)$ or $0.67 \mathrm{mmol} \cdot \mathrm{kg}^{-1}$ of enalapril $\left.\left(0.3 \mathrm{mg} \cdot \mathrm{kg}^{-1}\right)\right]$ was administered orally $90 \mathrm{~min}$ after equilibration of the glucose infusion rate during the hyperinsulinaemic euglycaemic clamp. The antihypertensive effect of delapril or enalapril used in clinical experiments was 4 times more potent than that of captopril [14]. Blood samples were taken from the contralateral cannulated cubital veins. Blood pressures and pulse rates were measured before and after administration of ACE inhibitors at 30-min intervals for $2 \mathrm{~h}$. Patients were studied on 3 separate days within a 2-week period.

\section{Euglycaemic clamp study}

In animal and clinical experiments, hyperinsulinaemic euglycaemic clamp tests were performed using the method of DeFronzo et al. [16].

The glucose infusion unit of the AEP kept blood glucose at the basal level during the entire study by means of an adequate i.v. glucose infusion. This was programmed by the computer of the system according to the control algorithm: $\operatorname{GIR}(\mathrm{t})=\mathrm{Cp}$ $[\mathrm{BG} p-\mathrm{BG}(\mathrm{t}-\tau)]+\mathrm{Cd}[-\Delta \mathrm{BG}(\mathrm{t}-\tau)]$, where $\mathrm{GIR}(\mathrm{t})$ is glucose infusion rate; $B G p$ is the projected value of blood glucose concentration; $\mathrm{BG}(\mathrm{t})$ and $\triangle \mathrm{BG}(\mathrm{t})$ are blood glucose concentrations and the rate of change in blood glucose concentration at time $t$; $\mathrm{Cp}$ and $\mathrm{Cd}$ are coefficients for glucose infusion; and $\tau(\mathrm{min})$ is the time delay constant for glucose infusion [17]. Optimal parameters of $\mathrm{Cp}, \mathrm{Cd}$ and $\tau$ were selected as $0.2,20$ and 3, respectively. The projected value of blood glucose concentration was set at $5.5 \mathrm{mmol} \cdot \mathrm{I}^{-1}$. No empirical correction was superimposed to reduce glucose variations during the tests.

After an initial $50 \mathrm{mU} \cdot \mathrm{kg}^{-1}$ injection of a short-acting insulin (Actrapid MC; Novo Nordisk Pharma. Inc.), it was then continuously infused at a rate of $1.12 \mathrm{mU} \cdot \mathrm{kg}^{-1} \cdot \mathrm{min}^{-1}$, during which the blood glucose concentration was held constant at the fasting level or $5.5 \mathrm{mmol} \cdot 1^{-1}$ by AEP. During the euglycaemic clamp study, venous samples were drawn at the time of $-30,0$, 30,60 and $90 \mathrm{~min}$ after the ACE inhibitor or bradykinin administration in animal and clinical experiments, and their plasma. glucose, insulin and bradykinin concentrations were measured. The insulin sensitivity index $\left(10^{-2} \cdot \mu \mathrm{U}^{-1} \cdot \mathrm{ml}^{2} \cdot \mathrm{kg}^{-1} \cdot \mathrm{min}^{-1}\right)$, which was calculated by dividing the glucose infusion rate by the incremental plasma insulin and clamped glucose value [18], was evaluated and compared. As a control in each experimental group, the results were expressed as a mean of two determina-
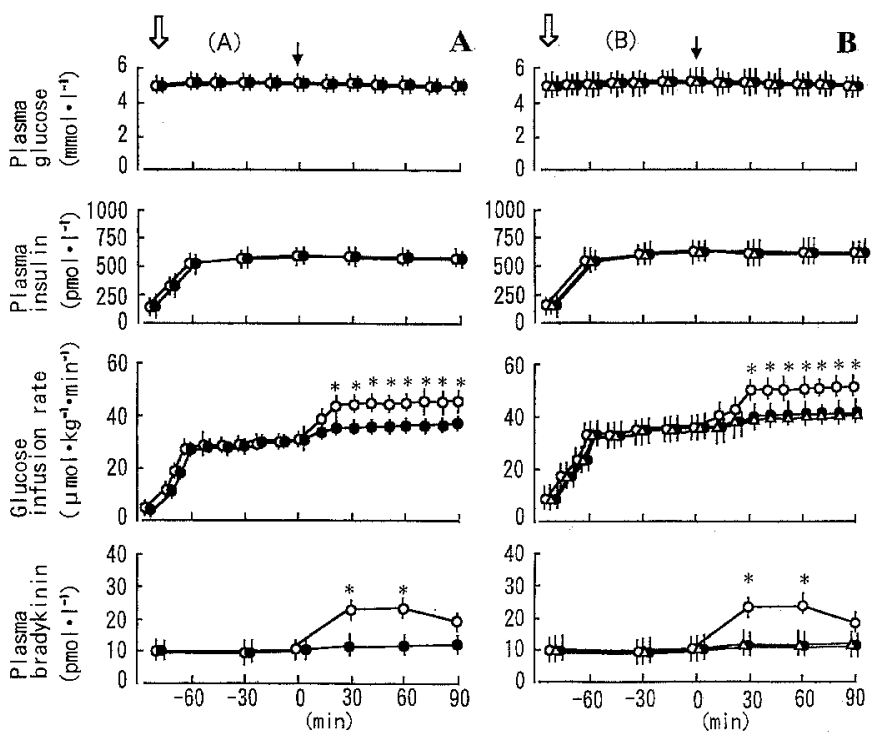

Fig.1 A,B. Effects on plasma concentrations of glucose, insulin and bradykinin, and glucose infusion rates of i. v. or oral administration of ACE inhibitors during hyperinsulinaemic euglycaemic clamp in healthy control dogs. After an initial $50 \mathrm{mU} \cdot \mathrm{kg}^{-1}$ injection of a short-acting insulin $(\downarrow)$, it was then continuously infused at a rate of $1.12 \mathrm{mU} \cdot \mathrm{kg}^{-1} \cdot \mathrm{min}^{-1}$. ACE inhibitors were administered i.v. or orally $(\downarrow)$ after the equilibration of glucose infusion rate. (A) Captopril ( $O$ ) or an active metabolite of delapril ( $)$ was injected as a bolus i.v. at a dose of $3.0 \mathrm{mmol} \cdot \mathrm{kg}^{-1}$ (0.6 or $1.5 \mathrm{mg} \cdot \mathrm{kg}^{-1}$, respectively). (B) Captopril $(O)$, delapril $(\bullet)$ or enalapril $(\Delta)$ was administered orally at a dose of $5.0 \mathrm{mmol} \cdot \mathrm{kg}^{-1}\left(1.0,2.5\right.$ or $2.5 \mathrm{mg} \cdot \mathrm{kg}^{-1}$, respectively). Values are mean $\pm \operatorname{SEM}(n=6)$. * $p<0.05$, before vs after treatment

tions at -30 and 0 min before administration, and compared with those of a mean of two determinations at 30 and 60 min after administration of ACE inhibitors.

\section{Assays}

Plasma glucose concentrations were measured using the glucose oxidase method (Autoanalyzer; Technicon Instruments Corp., Tarrytown, NY, USA) and plasma insulin concentrations were determined by radioimmunoassay (Eiken Immunochemical Laboratory, Tokyo, Japan).

Plasma bradykinin concentrations were measured by radioimmunoassay (Otsuka Assay Laboratory, Tokushima, Japan) [19]. Plasma samples were treated with proteinase inhibitors and EDTA, and then frozen until assayed. The detection limit was $2.5 \mathrm{pmol} \cdot \mathrm{1}^{-1}$. Intra- and inter-assay variations were $2.2-6.3$ and $4.9-12.6 \%$, respectively.

Captopril, delapril and its active metabolite, and enalapril maleate were kindly supplied by Sankyo Co. Ltd. (Tokyo, Japan), Takeda Pharmaceutical Co. Ltd. (Osaka, Japan) and Banyu Pharmaceutical Co. Ltd. (Tokyo, Japan) respectively. Bradykinin and bradykinin antagonist ( $N$ - $\alpha$-adamantaneacetylD-Arg-[Hyp $\left.{ }^{3}, \mathrm{Thi}^{5,8}, \mathrm{D}-\mathrm{Phe}^{7}\right]$-bradykinin) [20] were purchased from Sigma Chemical Co. Ltd. (St. Louis, Mo., USA). 
Table 2. Effects on insulin sensitivity indices and plasma bradykinin concentrations of $i$. v. or oral administration of ACE inhibitors, bradykinin antagonist or bradykinin in dog experiments

\begin{tabular}{|c|c|c|c|c|c|c|}
\hline \multirow[t]{2}{*}{ Treatment } & & \multirow[b]{2}{*}{$n$} & \multicolumn{2}{|c|}{$\begin{array}{l}\text { Insulin sensitivity index } \\
\left(10^{-2} \cdot \mu \mathrm{U}^{-1} \cdot \mathrm{ml}^{2} \cdot \mathrm{kg}^{-1} \cdot \mathrm{min}^{-1}\right)\end{array}$} & \multicolumn{2}{|c|}{$\begin{array}{l}\text { Plasma bradykinin } \\
\text { concentration }\left(\mathrm{pmol} \cdot \mathrm{l}^{-1}\right)\end{array}$} \\
\hline & & & Before & After & Before & After \\
\hline \multicolumn{7}{|l|}{ Healthy control dogs } \\
\hline Saline & (i.v. $0.15 \mathrm{~mol} \cdot \mathrm{l}^{-1}$ ) & 6 & $12.6 \pm 0.2$ & $12.7 \pm 0.2$ & $10.7 \pm 0.5$ & $10.6 \pm 0.5$ \\
\hline Captopril & (i.v. $3.0 \mathrm{mmol} \cdot \mathrm{kg}^{-1}$ ) & 6 & $12.8 \pm 0.1$ & $17.3 \pm 0.2^{b}$ & $10.2 \pm 1.4$ & $23.9 \pm 2.4^{\mathrm{b}}$ \\
\hline $\begin{array}{l}\text { Active metabolite } \\
\text { of delapril }\end{array}$ & (i.v. $3.0 \mathrm{mmol} \cdot \mathrm{kg}^{-1}$ ) & 6 & $12.6 \pm 0.1$ & $14.1 \pm 0.1$ & $10.3 \pm 0.8$ & $12.6 \pm 0.9$ \\
\hline Captopril & (oral, $5.0 \mathrm{mmol} \cdot \mathrm{kg}^{-1}$ ) & 6 & $13.2 \pm 0.2$ & $17.1 \pm 0.4^{\mathrm{b}}$ & $10.6 \pm 0.7$ & $24.2 \pm 1.2^{\mathrm{b}}$ \\
\hline Delapril & (oral, $5.0 \mathrm{mmol} \cdot \mathrm{kg}^{-1}$ ) & 6 & $13.8 \pm 0.2$ & $15.1 \pm 0.3$ & $10.7 \pm 0.4$ & $12.9 \pm 0.7$ \\
\hline Enalapril & (oral, $5.0 \mathrm{mmol} \cdot \mathrm{kg}^{-1}$ ) & 6 & $12.9 \pm 0.2$ & $14.0 \pm 0.4$ & $10.0 \pm 0.4$ & $12.1 \pm 0.7$ \\
\hline $\begin{array}{l}\text { Captopril with } \\
\text { bradykinin antagonist }\end{array}$ & $\begin{array}{l}\text { (i.v. } 3.0 \mathrm{mmol} \cdot \mathrm{kg}^{-1} \text { ) } \\
\text { (i.v. } 0.5 \mathrm{nmol} \cdot \mathrm{kg}^{-1} \cdot \mathrm{min}^{-1} \text { ) }\end{array}$ & 6 & $12.9 \pm 0.1$ & $13.1 \pm 0.3$ & & \\
\hline Bradykinin & (i.v. $0.03 \mathrm{nmol} \cdot \mathrm{kg}^{-1} \cdot \mathrm{min}^{-1}$ ) & 6 & $12.7 \pm 0.2$ & $14.2 \pm 0.5$ & $10.8 \pm 0.7$ & $14.1 \pm 2.5$ \\
\hline Bradykinin & (i.v. $0.1 \mathrm{nmol} \cdot \mathrm{kg}^{-1} \cdot \mathrm{min}^{-1}$ ) & 6 & $12.6 \pm 0.2$ & $18.3 \pm 0.8^{\mathrm{b}}$ & $10.6 \pm 0.7$ & $34.5 \pm 4.2^{b}$ \\
\hline \multicolumn{7}{|c|}{ Depancreatized diabetic dogs } \\
\hline Saline & (i.v. $0.15 \mathrm{~mol} \cdot \mathrm{1}^{-1}$ ) & 6 & $10.3 \pm 0.2$ & $10.2 \pm 0.4$ & $10.1 \pm 0.3$ & $10.0 \pm 0.5$ \\
\hline Captopril & (i.v. $3.0 \mathrm{mmol} \cdot \mathrm{kg}^{-1}$ ) & 6 & $10.5 \pm 0.3^{\mathrm{a}}$ & $16.4 \pm 0.5^{b}$ & $9.8 \pm 0.4$ & $22.9 \pm 2.5^{b}$ \\
\hline $\begin{array}{l}\text { Active metabolite } \\
\text { of delapril }\end{array}$ & (i.v. $3.0 \mathrm{mmol} \cdot \mathrm{kg}^{-1}$ ) & 6 & $9.7 \pm 0.3^{\mathrm{a}}$ & $12.5 \pm 0.4$ & $10.7 \pm 0.5$ & $12.5 \pm 0.6$ \\
\hline Captopril & (oral, $5.0 \mathrm{mmol} \cdot \mathrm{kg}^{-1}$ ) & 6 & $9.7 \pm 0.3^{\mathrm{a}}$ & $15.2 \pm 0.4^{\mathrm{b}}$ & $9.8 \pm 0.4$ & $22.6 \pm 2.8^{b}$ \\
\hline Delapril & (oral, $5.0 \mathrm{mmol} \cdot \mathrm{kg}^{-1}$ ) & 6 & $9.8 \pm 0.3^{\mathrm{a}}$ & $11.2 \pm 0.4$ & $9.6 \pm 0.4$ & $11.5 \pm 0.5$ \\
\hline Enalapril & (oral, $5.0 \mathrm{mmol} \cdot \mathrm{kg}^{-1}$ ) & 6 & $9.0 \pm 0.3^{\mathrm{a}}$ & $10.8 \pm 0.4$ & $9.1 \pm 0.3$ & $10.9 \pm 0.5$ \\
\hline $\begin{array}{l}\text { Captopril with } \\
\text { bradykinin antagonist }\end{array}$ & $\begin{array}{l}\text { (i.v. } 3.0 \mathrm{mmol} \cdot \mathrm{kg}^{-1} \text { ) } \\
\text { (i.v. } 0.5 \mathrm{nmol} \cdot \mathrm{kg}^{-1} \cdot \mathrm{min}^{-1} \text { ) }\end{array}$ & 6 & $10.4 \pm 0.1^{\mathrm{a}}$ & $10.0 \pm 0.3$ & & \\
\hline Bradykinin & (i.v. $0.03 \mathrm{nmol} \cdot \mathrm{kg}^{-1} \cdot \mathrm{min}^{-1}$ ) & 6 & $10.2 \pm 0.3^{\mathrm{a}}$ & $12.8 \pm 0.4$ & $10.2 \pm 0.5$ & $13.1 \pm 1.1$ \\
\hline Bradykinin & (i.v. $0.1 \mathrm{nmol} \cdot \mathrm{kg}^{-1} \cdot \mathrm{min}^{-1}$ ) & 6 & $10.5 \pm 0.3^{\mathrm{a}}$ & $16.9 \pm 0.5^{\mathrm{b}}$ & $9.4 \pm 0.4$ & $26.3 \pm 2.7^{b}$ \\
\hline
\end{tabular}

ACE inhibitors at a dose of $1.0 \mathrm{mmol} \cdot \mathrm{kg}^{-1}$ are equivalent to $0.2,0.5$ and $0.5 \mathrm{mg} \cdot \mathrm{kg}^{-1}$ in captopril, delapril and enalapril, respectively. ${ }^{\mathrm{a}} p<0.05$ vs healthy control dogs. ${ }^{\mathrm{b}} p<0.05$ vs before treatment

\section{Statistical analysis}

All data are expressed as mean \pm SEM. Statistical analysis was performed using the Student's $t$-test.

\section{Results}

\section{Animal experiments}

During hyperinsulinaemic euglycaemic clamp studies in the dog experiments, plasma glucose concentrations were clamped at $5.3 \pm 0.2 \mathrm{mmol} \cdot 1^{-1} \cdot(5.2 \pm 0.2$ and $5.4 \pm 0.2 \mathrm{mmol} \cdot 1^{-1}$ in healthy control and depancreatized diabetic dogs, respectively). Plasma insulin concentrations were clamped at $550 \pm 35 \mathrm{pmol} \cdot 1^{-1}$ (559 \pm 41 and $545 \pm 35 \mathrm{pmol} \cdot \mathrm{I}^{-1}$ in the two groups, respectively).

Effect on insulin sensitivity of ACE inhibitors. Figure 1 shows the effect on plasma concentration of glucose, insulin and bradykinin, and glucose infusion rates of i.v. or oral administration of ACE inhibitors during hyperinsulinaemic euglycaemic clamp tests in healthy control dogs. Table 2 summarizes the effects on insulin sensitivity indices and plasma bradykinin concentrations of ACE inhibitors, bradykinin antagonist or bradykinin in healthy control and depancreatized diabetic dogs.

As shown in Figure 1 and Table 2, in healthy control dogs, glucose infusion rates increased from the basal steady-state levels of $31.3 \pm 2.1$ to the significantly higher levels of $42.2 \pm 3.9 \mu \mathrm{mol} \cdot \mathrm{kg}^{-1} \cdot \mathrm{min}^{-1}$ at $20 \mathrm{~min}$ after i.v. administration or from $34.4 \pm 3.2$ to $49.4 \pm 4.7 \mu \mathrm{mol} \cdot \mathrm{kg}^{-1} \cdot \mathrm{min}^{-1}$ at $30 \mathrm{~min}$ after oral administration of captopril, respectively. Accordingly, insulin sensitivity indices increased significantly from $12.8 \pm 0.1$ to $17.3 \pm 0.2$ after i. v. administration or from $13.2 \pm 0.2$ to $17.1 \pm 0.410^{-2} \cdot \mu \mathrm{U}^{-1} \cdot \mathrm{ml}^{2} \cdot \mathrm{kg}^{-1} \cdot \mathrm{min}^{-1}$ after oral administration of captopril, respectively (Table 2). Concomitantly with these increases in insulin sensitivity indices, plasma bradykinin concentrations increased significantly from $10.2 \pm 1.4$ to $23.9 \pm 2.4 \mathrm{pmol} \cdot 1^{-1}$ after i.v. administration or from 
Table 3. Effects on insulin sensitivity indices and plasma bradykinin concentrations of oral administration of ACE inhibitors in clinical experiments

\begin{tabular}{|c|c|c|c|c|c|c|}
\hline \multirow[t]{2}{*}{ Treatment } & & \multirow[b]{2}{*}{$n$} & \multicolumn{2}{|c|}{$\begin{array}{l}\text { Insulin sensitivity index } \\
\left(10^{-2} \cdot \mu \mathrm{U}^{-1} \cdot \mathrm{ml}^{2} \cdot \mathrm{kg}^{-1} \cdot \mathrm{min}^{-1}\right)\end{array}$} & \multicolumn{2}{|c|}{$\begin{array}{l}\text { Plasma bradykinin concentration } \\
\left(\mathrm{pmol} \cdot 1^{-1}\right)\end{array}$} \\
\hline & & & Before & After & Before & After \\
\hline \multicolumn{7}{|c|}{ Normotensive healthy subjects } \\
\hline $\begin{array}{l}\text { Captopril } \\
\text { Delapril } \\
\text { Enalapril }\end{array}$ & $\begin{array}{l}\left(2.0 \mathrm{mmol} \cdot \mathrm{kg}^{-1}\right) \\
\left(2.0 \mathrm{mmol} \cdot \mathrm{kg}^{-1}\right) \\
\left(0.67 \mathrm{mmol} \cdot \mathrm{kg}^{-1}\right)\end{array}$ & $\begin{array}{l}8 \\
8 \\
8\end{array}$ & $\begin{array}{l}13.7 \pm 0.4 \\
13.4 \pm 0.4 \\
13.1 \pm 0.4\end{array}$ & $\begin{array}{l}17.3 \pm 0.5^{c} \\
15.4 \pm 0.4 \\
14.9 \pm 0.6\end{array}$ & $\begin{array}{l}10.6 \pm 0.4 \\
11.2 \pm 0.4 \\
11.5 \pm 0.6\end{array}$ & $\begin{array}{l}22.8 \pm 2.3^{\mathrm{c}} \\
13.3 \pm 0.5 \\
13.0 \pm 1.1\end{array}$ \\
\hline \multicolumn{7}{|c|}{ Hypertensive non-diabetic patients } \\
\hline $\begin{array}{l}\text { Captopril } \\
\text { Delapril } \\
\text { Enalapril }\end{array}$ & $\begin{array}{l}\left(2.0 \mathrm{mmol} \cdot \mathrm{kg}^{-1}\right) \\
\left(2.0 \mathrm{mmol} \cdot \mathrm{kg}^{-1}\right) \\
\left(0.67 \mathrm{mmol} \cdot \mathrm{kg}^{-1}\right)\end{array}$ & $\begin{array}{l}8 \\
8 \\
8\end{array}$ & $\begin{array}{l}9.1 \pm 0.6^{\mathrm{a}} \\
9.7 \pm 0.3^{\mathrm{a}} \\
9.6 \pm 0.3^{\mathrm{a}}\end{array}$ & $\begin{array}{l}12.8 \pm 0.7^{\mathfrak{c}} \\
10.8 \pm 0.4 \\
10.0 \pm 0.5\end{array}$ & $\begin{array}{l}10.2 \pm 0.4 \\
10.6 \pm 0.4 \\
10.1 \pm 0.5\end{array}$ & $\begin{array}{l}22.3 \pm 2.0^{c} \\
12.4 \pm 0.3 \\
11.9 \pm 0.4\end{array}$ \\
\hline \multicolumn{7}{|c|}{ Normotensive NIDDM patients } \\
\hline $\begin{array}{l}\text { Captopril } \\
\text { Delapril } \\
\text { Enalapril }\end{array}$ & $\begin{array}{l}\left(2.0 \mathrm{mmol} \cdot \mathrm{kg}^{-1}\right) \\
\left(2.0 \mathrm{mmol} \cdot \mathrm{kg}^{-1}\right) \\
\left(0.67 \mathrm{mmol} \cdot \mathrm{kg}^{-1}\right)\end{array}$ & $\begin{array}{l}8 \\
8 \\
8\end{array}$ & $\begin{array}{l}7.4 \pm 0.4^{\mathrm{a}} \\
6.8 \pm 0.2^{\mathrm{a}} \\
6.5 \pm 0.2^{\mathrm{a}}\end{array}$ & $\begin{array}{l}9.2 \pm 0.7^{c} \\
8.4 \pm 0.2 \\
7.6 \pm 0.3\end{array}$ & $\begin{array}{l}9.2 \pm 0.3 \\
9.8 \pm 0.5 \\
9.7 \pm 0.5\end{array}$ & $\begin{array}{l}20.2 \pm 1.8^{c} \\
11.6 \pm 0.5 \\
11.4 \pm 0.6\end{array}$ \\
\hline \multicolumn{7}{|c|}{ Hypertensive NIDDM patients } \\
\hline $\begin{array}{l}\text { Captopril } \\
\text { Delapril } \\
\text { Enalapril }\end{array}$ & $\begin{array}{l}\left(2.0 \mathrm{mmol} \cdot \mathrm{kg}^{-1}\right) \\
\left(2.0 \mathrm{mmol} \cdot \mathrm{kg}^{-1}\right) \\
\left(0.67 \mathrm{mmol} \cdot \mathrm{kg}^{-1}\right)\end{array}$ & $\begin{array}{l}8 \\
8 \\
8\end{array}$ & $\begin{array}{l}5.0 \pm 0.4^{\mathrm{a}, \mathrm{b}} \\
5.0 \pm 0.3^{\mathrm{a}, \mathrm{b}} \\
5.2 \pm 0.3^{\mathrm{a}, \mathrm{b}}\end{array}$ & $\begin{array}{l}7.5 \pm 0.5^{\mathrm{c}} \\
6.6 \pm 0.3 \\
6.2 \pm 0.7\end{array}$ & $\begin{array}{l}8.6 \pm 0.4 \\
9.3 \pm 0.4 \\
8.9 \pm 0.3\end{array}$ & $\begin{array}{l}19.6 \pm 1.8^{c} \\
11.8 \pm 0.4 \\
10.2 \pm 0.3\end{array}$ \\
\hline
\end{tabular}

ACE inhibitors at a dose of $1.0 \mathrm{mmol} \cdot \mathrm{kg}^{-1}$ are equivalent to $0.2,0.5$ and $0.5 \mathrm{mg} \cdot \mathrm{kg}^{-1}$ in captopril, delapril and enalapril, respectively. ${ }^{\mathrm{a}} p<0.05$ vs before treatment in normotensive healthy subjects. ${ }^{\mathrm{b}} p<0.05$ vs before treatment in normotensive NIDDM patients. ${ }^{c} p<0.05$ vs before treatment

$10.6 \pm 0.7$ to $24.2 \pm 1.2 \mathrm{pmol} \cdot 1^{-1}$ after oral administration of captopril, respectively. In comparison, i.v. administration of an active metabolite of delapril and oral administration of either delapril or enalapril showed slight, but not significant increases in insulin sensitivity indices and plasma bradykinin concentrations.

In depancreatized diabetic dogs, insulin sensitivity indices were $10.0 \pm 0.210^{-2} \cdot \mu \mathrm{U}^{-1} \cdot \mathrm{ml}^{2} \cdot \mathrm{kg}^{-1} \cdot \mathrm{min}^{-1}$. These values were significantly lower than those of healthy control dogs $\left(12.9 \pm 0.110^{-2} \cdot \mu \mathrm{U}^{-1} \cdot \mathrm{ml}^{2} \cdot \mathrm{kg}^{-1}\right.$. $\mathrm{min}^{-1}$ : mean of 24 dogs). As in healthy control dogs, insulin sensitivity indices improved significantly in depancreatized diabetic dogs after i. v. or oral administration of captopril. These improvements in insulin sensitivities were concomitant with the increases in plasma bradykinin concentrations. Again, i.v. injection of an active metabolite of delapril and oral administration of enalapril or delapril showed slight, but not significant effects on insulin sensitivity indices and plasma bradykinin concentrations.

Effect on insulin sensitivity of bradykinin antagonist and bradykinin. To test the possible effect of bradykinin on the improvement of insulin sensitivities, a bradykinin antagonist (N- $\alpha$-adamantaneacetyl-D-

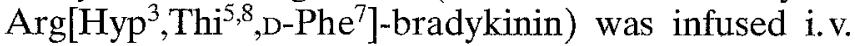
$30 \mathrm{~min}$ before captopril injection in healthy control and depancreatized diabetic dogs.

In both healthy control and depancreatized diabetic dogs, administration of the bradykinin antagonist abolished the effects of captopril on insulin sensitivity. In these experiments, venous plasma bradykinin concentrations could not be determined because anti-brady- kinin antibody in the bradykinin assay system crossreacted with the bradykinin antagonist.

Furthermore, to reveal the direct action of bradykinin on insulin sensitivity, bradykinin was infused i.v. into both healthy control and diabetic dogs. Intravenous administrations of bradykinin at concentrations of 0.03 and $0.1 \mathrm{nmol} \cdot \mathrm{kg}^{-1} \cdot \mathrm{min}^{-1}$ increased plasma bradykinin concentrations to the levels of $14.1 \pm 2.5$ and $34.5 \pm 4.2 \mathrm{pmol} \cdot 1^{-1}$ in healthy control dogs and $13.1 \pm 1.1$ and $26.3 \pm 2.7 \mathrm{pmol} \cdot 1^{-1}$ in diabetic dogs. Concomitant with the increase in plasma bradykinin concentrations, insulin sensitivity indices increased significantly after i.v. administration of bradykinin.

\section{Clinical experiments}

During hyperinsulinaemic euglycaemic clamp studies in clinical experiments, plasma glucose concentrations were clamped at $5.0 \pm 0.3 \mathrm{mmol} \cdot \mathrm{l}^{-1}(5.2 \pm 0.2,4.9 \pm 0.2$, $4.8 \pm 0.3$ and $5.2 \pm 0.4 \mathrm{mmol} \cdot \mathrm{1}^{-1}$ in normotensive healthy subjects, hypertensive non-diabetic patients, normotensive NIDDM patients and hypertensive NIDDM patients, respectively). Plasma insulin concentrations were clamped at $607 \pm 48 \mathrm{pmol} \cdot 1^{-1}$ (607 \pm $48,607 \pm 41,600 \pm 35$ and $614 \pm 41 \mathrm{pmol} \cdot \mathrm{l}^{-1}$ for these four groups, respectively).

In normotensive healthy subjects and normotensive NIDDM patients, after administration of ACE inhibitors blood pressure did not change significantly. However, in hypertensive non-diabetic patients, blood pressure decreased significantly from $150 \pm 5 / 92 \pm 3,152 \pm$ 
$4 / 95 \pm 3$ and $150 \pm 5 / 92 \pm 3$ to $135 \pm 4 / 83 \pm 2,124 \pm 6 / 79$ \pm 6 and $122 \pm 5 / 80 \pm 4 \mathrm{~mm} \mathrm{Hg}(p<0.01)$ at $60 \mathrm{~min}$ after oral administration of captopril, delapril and enalapril, respectively. Similarly, in hypertensive NIDDM patients, blood pressures decreased significantly from $156 \pm 6 / 96 \pm 4,154 \pm 6 / 94 \pm 4$ and $155 \pm 6 / 93 \pm 4$ to $141 \pm 7 / 86 \pm 5,134 \pm 8 / 84 \pm 5$ and $132 \pm 4 / 86 \pm 4 \mathrm{~mm} \mathrm{Hg}$ $(p<0.01)$ at $60 \mathrm{~min}$ in captopril, delapril and enalapril, respectively. However, ACE inhibitors did not influence the pulse rates in all four groups.

Effects on insulin sensitivity indices and plasma bradykinin concentrations of ACE inhibitors in normotensive and hypertensive patients are summarized in Table 3.

Insulin sensitivity indices decreased in the following order: normotensive healthy subjects, hypertensive non-diabetic patients, normotensive NIDDM patients and hypertensive NIDDM patients; $13.7 \pm 0.4,9.1 \pm 0.6$, $7.4 \pm 0.4$ and $5.0 \pm 0.410^{-2} \cdot \mu \mathrm{U}^{-1} \cdot \mathrm{ml}^{2} \cdot \mathrm{kg}^{-1} \cdot \mathrm{min}^{-1}$, respectively. Insulin sensitivity indices in hypertensive patients were significantly lower than those in normotensive patients.

Oral administration of captopril $\left(2.0 \mathrm{mmol} \cdot \mathrm{kg}^{-1}\right.$, $0.4 \mathrm{mg} \cdot \mathrm{kg}^{-1}$ ) significantly increased insulin sensitivity indices from basal values to $17.3 \pm 0.5,12.8 \pm 0.7$, $9.2 \pm 0.7$ and $7.5 \pm 0.510^{-2} \cdot \mu \mathrm{U}^{-1} \cdot \mathrm{ml}^{2} \cdot \mathrm{kg}^{-1} \cdot \mathrm{min}^{-1}$ in normotensive healthy subjects, hypertensive nondiabetic patients, normotensive NIDDM patients and hypertensive NIDDM patients, respectively. Concomitantly, plasma bradykinin concentrations significantly increased after oral administration of captopril from $10.6 \pm 0.4,10.2 \pm 0.4,9.2 \pm 0.3$ and $8.6 \pm 0.4 \mathrm{pmol} \cdot \mathrm{l}^{-1}$ to $22.8 \pm 2.3,22.3 \pm 2.0,20.2 \pm 1.8$ and $19.6 \pm 1.8$ pmol $\cdot$ $\mathrm{ml}^{-1}$ in normotensive healthy subjects, hypertensive non-diabetic patients, normotensive NIDDM patients and hypertensive NIDDM patients, respectively. By contrast, oral administration of enalapril or delapril showed slight, but not significant effects on insulin sensitivity indices and plasma bradykinin concentrations.

\section{Discussion}

DeFronzo et al. [21] elucidated the decreased insulin sensitivity in patients with impaired glucose tolerance or NIDDM using the euglycaemic clamp technique. Furthermore, using the same technique, Ferrannini et al. [22] demonstrated decreased insulin sensitivities in patients with essential hypertension. Compatible with their findings, the present study in both animal and clinical experiments demonstrated that insulin sensitivity was decreased in the hypertensive state whether or not glucose tolerance was impaired, and that insulin sensitivity in diabetes was significantly lower than that observed in the non-diabetic state. Insulin-stimulated glucose utilization in peripheral tissues is known to decrease significantly in hypertensive patients $[22,23]$. Nevertheless, hypertension is treated with antihyper- tensive drugs which may have adverse metabolic effects, and in particular may inhibit insulin secretion and impair the actions of insulin [2]. Among the antihypertensive drugs, however, ACE-inhibitors in addition to their antihypertensive effect, may improve insulin sensitivity.

Currently available ACE inhibitors were divided into two categories, those with (captopril) or without a sulphydryl group (delapril or enalapril). The antihypertensive effect of ACE inhibitors [delapril $\left(1.0 \mathrm{mg} \cdot \mathrm{kg}^{-1}\right)$ or enalapril $\left.\left(0.3 \mathrm{mg} \cdot \mathrm{kg}^{-1}\right)\right]$ used in our clinical experiments was 4 times more potent than that of captopril $\left(0.4 \mathrm{mg} \cdot \mathrm{kg}^{-1}\right)$, comparing the pharmacological data of these ACE inhibitors [14]. From these pharmacokinetic data, $T_{\max }$ values (time to the maximum serum concentration) were $0.86 \mathrm{~h}$ for captopril, $1 \mathrm{~h}$ for enalapril and $4 \mathrm{~h}$ for enalapril diacid, more potent active metabolite. The $\mathrm{T}_{\max }$ values of delapril and delapril diacid were similar to those of enalapril. With delapril or enalapril, however, plasma levels after oral administration of these agents increased as fast as those of captopril and were sustained longer than those of captopril [14]. As a result, more significant blood pressure lowering effects were observed after oral administration of delapril or enalapril, compared to those after captopril administration.

It is widely accepted that captopril has a beneficial effect on insulin sensitivity $[7,8]$. However, there have been confusing results as to ACE inhibitors without a sulphydryl group (delapril or enalapril). Using the minimal models proposed by Bergman et al. [18, 24], Paolisso et al. [9] reported that a 2-week treatment with ACE inhibitors either with or without a sulphydryl group improved insulin sensitivity in elderly hypertensive non-diabetic patients. On the other hand, Seefeldt et al. [10] demonstrated that treatment with enalapril had no effect on glucose metabolism in diabetic patients using the glucose clamp technique. In our evaluation of the acute effect on insulin sensitivity of ACE inhibitors with or without a sulphydryl group, we have clearly demonstrated in both dog and clinical experiments that ACE inhibitors with a sulphydryl group could significantly improve insulin sensitivity. This increase and/or improvement in insulin sensitivity after captopril administration, either intravenously or orally, was concomitant with a significant increase in plasma bradykinin concentration. However, ACE inhibitors without a sulphydryl group showed slight, but not significant effects on insulin sensitivites and plasma bradykinin concentrations. From these experiments, it was suggested that the increase in plasma bradykinin concentrations might play a significant role in the improvement of insulin sensitivity.

ACE inhibitors without a sulphydryl group have been developed to eliminate the side effects caused by the sulphydryl group in captopril. Captopril contains a modified proline molecule with a mercapto moiety that binds with the zinc atom of the metalloenzyme ACE, 
thus inactivating ACE [25]. Enalapril, delapril and other second-generation ACE inhibitors differ from captopril in that they compete with the renin substrate for ACE binding sites [25]. The reason why ACE inhibitors with a sulphydryl group have more potent action on the improvement in insulin sensitivity, concomitant with a significant increase in plasma bradykinin concentrations, despite similar antihypertensive and cardiovascular effects remains unanswered. The possibility cannot be excluded that plasma bradykinin concentrations increase in the arterial blood stream after administration of ACE inhibitors without a sulphydryl group. Since the half-life of secreted bradykinin is less than $60 \mathrm{~s}$, plasma concentrations of bradykinin might not be high enough to demonstrate a significant increase in insulin sensitivity after administration of ACE inhibitors without a sulphydryl group (delapril or enalapril). After captopril is metabolized in the liver, the disulphide dimer has been reported to enhance the bradykinin-induced vasopressor response, although captopril disulphides are not themselves significant inhibitors of ACE [26-28]. Thus, the disulphide dimer produced after captopril administration might possibly protect further degradation of bradykinin, resulting in prolongation of the half-life.

In our present dog and clinical experiments, increases in insulin sensitivity indices after administration of an ACE inhibitor with a sulphydryl group were concomitant with a significant increase in plasma bradykinin concentration. In dog experiments, an infusion of a bradykinin antagonist $30 \mathrm{~min}$ before captopril injection abolished the captopril effect on insulin sensitivity. When testing the direct action of bradykinin on insulin sensitivity by infusing bradykinin at the same levels as observed after captopril injection, it was found that insulin sensitivity indices significantly increased. These findings were in agreement with reports by Hartl et al. [29] who described that bradykinin infused at the rate of $0.03 \mathrm{nmol} \cdot \mathrm{kg}^{-1} \cdot \mathrm{min}^{-1}$ had a positive effect on insulin sensitivity in insulin-resistant post-operative and NIDDM patients without any systemic haemodynamic changes [30]. Therefore, plasma bradykinin concentrations after captopril administration might have a significant role in the improvement of insulin sensitivity.

The influence of ACE inhibitors with a sulphydryl group on insulin sensitivity might be explained through haemodynamic and/or hormonal hypotheses. Vasodilation or constriction may significantly affect peripheral glucose uptake [31]. As suggested by Bergman et al. [24], vasodilation decreases the distance between feeding capillaries (capillary recruitment) with a secondary improvement in the insulin concentration gradient between the capillary and surrounding muscle. This haemodynamic hypothesis is supported by the finding of Kodama et al. [32] who have demonstrated that an increase in forearm blood flow may play a key role in the increase in glucose handling after captopril admin- istration. As a potent vasodilator, increased plasma bradykinin concentrations after captopril might also be responsible for vasodilation.

As to the hormonal hypothesis, after ACE-inhibition, Dietze et al. [33] and Jauch et al. [34] reported that the reduced degradation of bradykinin might exert an insulin-like activity. In our preliminary experiments with adipocytes isolated from dog adipose tissue, increases in glucose uptake and autophosphorylation of insulin receptors were observed in cells incubated with bradykinin and insulin, without any significant increase in receptor numbers.

In the clinical experiments, we studied non-obese NIDDM patients, a patient group commonly observed in Japan. Further studies are necessary to elucidate the beneficial effect of captopril on insulin sensitivity in obese NIDDM patients with or without hypertension, who show much more insulin resistance than nonobese NIDDM patients.

In conclusion, our dog and clinical experiments demonstrate that ACE inhibitors with a sulphydryl group have more potent action on insulin sensitivity than those without a sulphydryl group. This beneficial effect on insulin sensitivity might be mediated through plasma bradykinin levels. Captopril, which is an ACE inhibitor with a sulphydryl group may be the best choice for the treatment of diabetic patients with hypertension, unless severe diabetic nephropathy is present.

Acknowledgement. We thank Mr. K. Ichinose for his skillful work.

\section{References}

1. Ferrannini E, Galvan AQ (1992) Hyperinsulinemia, insulin resistance, and blood pressure. Hypertens Res 15: 67-75

2. Stein PP, Black HR (1991) Drug treatment of hypertension in patients with diabetes mellitus. Diabetes Care 14: 425-448

3. Zusman RM (1987) Effects of converting-enzyme inhibitors on the renin-angiotensin-aldosterone, bradykinin, and arachidonic acid-prostaglandin systems: correlation of chemical structure and biologic activity. Am J Kid Dis 10 [Suppl 1]: $13-23$

4. Chobanian AV, Haudenschild CC, Nickerson C, Drago R (1989) Anti-atherogenic effect of captopril in the Watanabe heritable hyperlipidemic rabbit. Hypertension 15: 327-331

5. Mehta JL, Nicolini FA, Lawson DL (1990) Sulphydryl group in angiotensin converting enzyme inhibitors and superoxide radical formation. J Cardiovasc Pharmacol 16: 847-849

6. Gavras H, Gavras I (1988) Angiotensin converting enzyme inhibitors properties and side effects. Hypertension 11 [Suppl II]: 37-41

7. Rett K, Lotz N, Wicklmayr M et al. (1988) Improved insulin action by ACE inhibitor in type II diabetes. Dtsch Med Wochenschr 113: 243-249

8. Torlone E, Rambotti AM, Periello G et al. (1991) ACE-inhibition increases hepatic and extrahepatic sensitivity to insulin in patients with type 2 (non-insulin-dependent) diabetes mellitus and arterial hypertension. Diabetologia 34: 119-125 
9. Paolisso G, Gambaldella A, Verza M, D’Amore A, Sgambato S, Varricchio M (1992) ACE inhibition improves insulinsensitivity in aged insulin-resistant hypertensive patients. J Hum Hypertens 6: 175-179

10. Seefeldt T, Ørskov L, Mengel A et al. (1990) Lack of effects on angiotensin-converting enzyme (ACE)-inhibitors on glucose metabolism in type 1 diabetes. Diabetes Med 7: 700-704

11. Bak JF, Gerdes LU, Sørensen NS, Pedersen O (1992) Effects of perindopril on insulin sensitivity and plasma lipid profile in hypertensive non-insulin-dependent diabetic patients. Am J Med 92: 69-72

12. Moore MP, Elliott TW, Nicholls MG (1988) Hormonal and metabolic effects of enalapril treatment in hypertensive subjects with NIDDM. Diabetes Care 11:397-401

13. Shichiri M, Kawamori R, Abe H (1979) Normalization of the paradoxic secretion of glucagon in diabetics who were controlled by the artificial beta cell. Diabetes $28: 272-275$

14. Shionoiri H, Yasuda G, Ikeda A et al. (1987) Pharmacokinetics and depressor effect of delapril in patients with essential hypertension. Clin Pharmacol Ther 41: 74-79

15. Joint National Committee (1988) The 1988 report of the joint national committee on detection, evaluation, and treatment of high blood pressure. Arch Intern Med 148: 1023-1038

16. DeFronzo RA, Tobin JD, Andres R (1979) Glucose clamp technique: a method for quantifying insulin secretion and resistance. Am J Physiol 237: E214-E223

17. Shichiri M, Kawamori R (1985) Optimized algorithms for closed-loop glycemic control systems. In: Beyer J, Albisser M, Schrezenmeir J, Lehmann L (eds) Computer systems for insulin adjustment in diabetes mellitus. Panscienta-Verlag, Hedingen, pp 171-183

18. Finegood DT, Pacini G, Bergman RN (1984) The insulin sensitivity index: correlation in dogs between values determined from the intravenous glucose tolerance test and the euglycemic glucose clamp. Diabetes 33: 362-368

19. Minami M, Togashi H, Sano M et al. (1983) Plasma bradykinin concentration in patients with essential hypertension, effort angina and other cardiac disease. Folia Endocrinol Jpn 82: 159-169

20. Lammek B, Wang Y, Gavras I, Gavras H (1990) A highly potent bradykinin antagonist with no agonist activity. Peptide 11: 1041-1043

21. DeFronzo RA (1988) Lilly lecture 1987: The triumvirate: $\beta$-cell, muscle, liver: a collusion responsible for NIDDM. Diabetes 36: 667-687
22. Ferrannini E, Buzzigoli G, Bonadonna R et al. (1987) Insulin resistance in essential hypertension. N Engl J Med 317: 350 357

23. Pollare T, Lithell H, Berne C (1989) A comparison of the effects of hydrochlorothiazide and captopril on glucose and lipid metabolism in patients with hypertension. $\mathrm{N}$ Engl J Med 321: 868-873

24. Bergman RN, Hope ID, Yang YJ et al. (1989) Assessment of insulin sensitivity in vivo: a critical review. Diabetes Metab Rev 5: 411-429

25. Patchett AA, Harris E, Tristram EW et al. (1980) A new class of angiotensin-converting enzyme inhibitors. Nature 288: 280-283

26. O'Hara N, Ono H, Hashimoto K (1982) Potentiation of bradykinin-induced decrease of blood pressure in dogs by SQ 14,551, the disulfide metabolite of captopril. Jpn J Pharmacol 32: 934-937

27. Drummer OH, Kourtis S, Jarrott B (1985) Inhibition of angiotensin converting enzyme by metabolites of captopril. Clin Exp Pharmacol Physiol [Suppl] 9: 12-16

28. Drummer OH, Kourtis S (1988) Bradykinin-potentiating activity of captopril disulphide dimer (SQ 14551). Eur J Pharmacol 153: 11-17

29. Hartl WH, Jauch KW, Herndon DN, Cohnert TU, Wolfe RR, Schidberg FW (1990) Effect of low-dose bradykinin on glucose metabolism and nitrogen balance in surgical patients. Lancet 335: 69-71

30. Wicklmayr M, Dietze G, Günther B, Boettger I, Mayer L, Janetschek P (1979) Improvement in glucose assimilation and protein degradation by bradykinin in maturity onset diabetics and in surgical patients. Kinins II: 569-576

31. Laasko M, Edelman V, Brecjtel G, Baron AD (1990) Decreased effect of insulin to stimulate skeletal muscle blood flow in obese men. A novel mechanism for insulin resistance. J Clin Invest 85: 1844-1852

32. Kodama J, Kitayama S, Tanaka K, Itabashi A, Kawazu S, Ishii J (1990) Effect of captopril on glucose concentration: possible role of augmented postprandial forearm blood flow. Diabetes Care 13: 1109-1111

33. Dietze G (1982) Modulation of the action of insulin in relation to the energy state in skeletal muscle. Possible involvement of kinins and prostaglandins. Mol Cell Endocrinol 25: 127-149

34. Jauch KW, Günther B, Hartl W, Rett K, Wicklmayr M, Dietze G (1986) Improvement of impaired post-operative insulin action by bradykinin. Biochem Chem Hoppe Seyler 367:207-210 